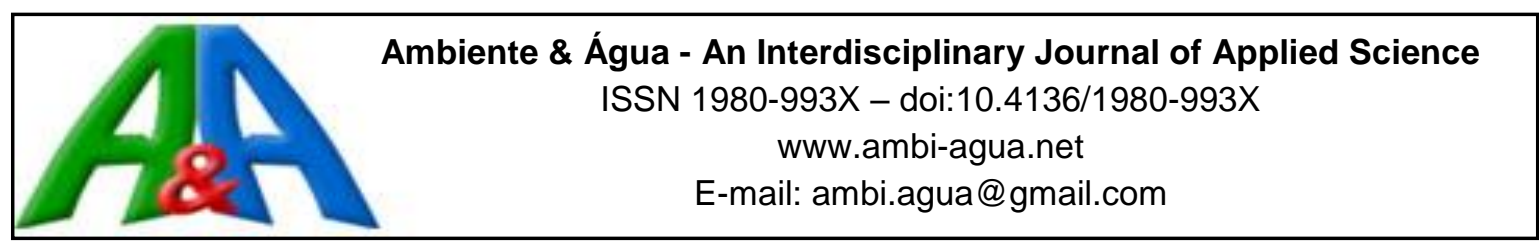

\title{
Management of phosphorus in water: case study of the Tietê River, Brazil
}

\author{
doi:10.4136/ambi-agua.1977
}

Received: 28 Jul. 2016; Accepted: 04 Sep. 2017

\author{
Claudia Maria Gomes de Quevedo*; Wanderley da Silva Paganini \\ Universidade de São Paulo (USP), São Paulo, SP, Brasil \\ Faculdade de Saúde Pública (FSP). E-mail: claugomes@usp.br, paganini@usp.br \\ *Corresponding author
}

\begin{abstract}
Strategies for managing phosphorus in the environment have been considered to be of great significance. In light of debates about protecting water resources, tools for recovering and recycling phosphorus are being assessed, with the aim of guaranteeing the sustainability of natural reserves. This study discusses phosphorus dynamics in the environment and measures geared towards the management of its presence in water. In order to illustrate the situation in Brazil, we present an assessment of the size of the potential phosphorus load that is discharged daily into the Tietê River, State of São Paulo, by the urban population living in its basin. Due to its replacement in powdered detergents, the results showed a potential reduction in the amount of phosphorus discharged into the Tietê of about $11.7 \mathrm{t} \mathrm{day}^{-1}$. The size of the potential phosphorus load that might be recovered from sewage sludge shows a scenario of great potential for re-using and recycling in agricultural areas, as long as the necessary care is taken regarding safety and environmental protection. Management methodologies, such as Cleaner Production (CP) techniques, are important tools for controlling water pollution, as they contribute to the reduction of phosphorus emissions. They can therefore improve the perception producers and consumers have of this issue, introducing reducing, recycling and recovering concepts, and assisting in compliance with public policies geared towards preserving the environment.
\end{abstract}

Keywords: effluent, nutrients, water quality.

\section{A gestão do fósforo nas águas: estudo de caso do Rio Tietê, Brasil}

\section{RESUMO}

O desenvolvimento de estratégias para gestão do fósforo nas águas tem sido considerado, cada vez mais, de grande importância para a manutenção da qualidade de vida. Assim, paralelamente às discussões sobre alternativas para promover a proteção das águas, são avaliadas ferramentas para controle das fontes e reciclagem do fósforo no meio ambiente, buscando garantir a sustentabilidade das reservas conhecidas e exploráveis. Face ao exposto, o objetivo deste trabalho é discutir a dinâmica do fósforo no meio ambiente e as medidas voltadas para a gestão de sua presença nas águas. A título de ilustração da situação vivenciada no Brasil a respeito desse assunto, apresenta-se um dimensionamento da carga potencial de fósforo lançada diariamente nas águas do rio Tietê, localizado no Estado de São Paulo, a partir da população urbana da bacia hidrográfica. Os resultados obtidos demonstram um potencial de 
redução na quantidade de fósforo lançada nas águas do Tietê devido à sua substituição nos detergentes em pó da ordem de 11,7 $\mathrm{t} \mathrm{dia}^{-1}$. O dimensionamento da quantidade de fósforo que pode ser removida do lodo de esgoto demonstra um cenário de grande potencial de reutilização e reciclagem em áreas agrícolas, desde que tomados os cuidados necessários com relação à proteção à saúde e ao meio ambiente. As ferramentas de gestão, a exemplo das técnicas de Produção Mais Limpa $(\mathrm{P}+\mathrm{L})$, surgem como uma importante ferramenta de controle da poluição das águas, na medida em que pode contribuir para redução das emissões de fósforo. Também, podem contribuir para o aprimoramento da percepção dos produtores e consumidores acerca do assunto, introduzindo conceitos de redução, reutilização e reciclagem, e auxiliando no cumprimento de políticas públicas voltadas para a preservação ambiental.

Palavras-chave: efluente, nutrientes, qualidade das águas.

\section{INTRODUCTION}

Phosphorus is a chemical element that is used in industrial processes as a raw material in both the composition and the processing of products and also as an agent to improve the productive process. Its natural source is the lithosphere.

As well as having economic importance, phosphorus is considered a vital element in biological processes, as it is essential for the formation of deoxyribonucleic acid (DNA), ribonucleic acid (RNA) and adenosine triphosphate (ATP), the nucleotide responsible for storing energy derived from cellular respiration and photosynthesis.

Given that phosphorus is not toxic to living organisms - on the contrary, it is essential for life - in relation to the environment it is associated with levels of fertilization in water systems, that is, eutrophication. This process can contribute to the deterioration of water quality and may render water unusable, thus becoming a significant environmental and public health issue.

Furthermore, in the last decades predictions about the exhaustion of phosphorus sources and the impossibility of replacing it within biological processes have led to discussions about the impacts of its industrial uses. Thus, along with discussions about alternatives means of protecting water resources, tools for controlling sources and recycling phosphorus in the environment are being evaluated, in order to guarantee the sustainability of known and exploitable reserves in an integrated way.

Within this context, Cleaner Production (CP) concepts emerge as a way of preventing pollution and linking economic and technological objectives to more-sustainable practices, thus improving water quality and preserving phosphorous sources, promoting greater efficiency in the use of this raw material and sustaining quality of life for present and future generations.

This study therefore discusses the presence of phosphorus in water, presenting practices that have already been adopted, geared towards the control and management of its loads. For illustrative purposes, we present a case study about the loads of phosphorus derived from sewage discharged into the waters of the Tietê, a Brazilian river in the State of São Paulo.

\subsection{Sources of phosphorus in water: management and control measures}

The phosphorus input in rivers and reservoirs is directly related to the size and concentration of natural or artificial sources in the water basin.

In regions that are economically developed and have a large population concentration, the presence of phosphorus is usually related to the so-called artificial or anthropic (man-produced) sources. In these places, although they also experience phosphorus input due to natural processes, it is estimated that artificial sources are much more significant and among these sources; we could highlight domestic sewage, industrial effluents and superficial drainage of cultivated areas (IJC, 1970; Chave, 1997; Von Sperling et al., 2009). 
With regard to industrial activity, the use of organophosphorus compounds is associated with either their employment in the composition and the processing of products or with the performance of the productive process itself. In the latter case, for example, polyphosphates are widely used to minimize or avoid problems such as boiler incrustation, and to reduce chemical precipitation in cooling systems and heat exchanges and, more recently, in desalination plants. In effluents originating from product processing, the presence of phosphates is basically related to activities such as the food industry, sugar and alcohol refining, the manufacturing of cleaning products, such as detergents, and the finishing of metals (Braile and Cavalcanti, 1993).

According to Glennie et al. (2002), we can consider that the main anthropic sources of phosphorus in water are domestic sewage and agricultural activity. In places where agriculture is less intensive, domestic sewage is the most significant source and measures to reduce and control the amount of sewage discharged through effluents are necessary to improve the quality of the water system.

In agriculture, the use of phosphorus is related to guaranteeing productivity. Due to its reduced soil mobility, phosphorus is considered a nutrient that is taken up at low levels by plants. Consequently, fertilizers are always applied in larger amounts than a plant's ability to extract them. However, the continuous and long-term application of fertilizers can increase the concentration of phosphorus in the soil and contribute to the loss of this nutrient through superficial drainage. The phosphorus loss coefficient in agricultural areas varies between 0.15 and $1.4 \mathrm{~kg}$ ha.year ${ }^{-1}$ (Vollenweider, 1968; Glennie et al., 2002; Sharpley et al., 2003). In the Brazilian state of São Paulo, the potential phosphorus losses in cultivated areas is around $5,045 \mathrm{t} \mathrm{year}^{-1}$ or $0.20 \mathrm{~kg}$ ha.year ${ }^{-1}$. This value is derived from the average rate of the phosphorus concentration in soil and the amount of fertilizers used in the region, calculated at $0.002614 \%$. It also considers the losses of soil from the erosive processes and the run-off because of rainfall, estimated at 193 million t year ${ }^{-1}$ (Bellinazzi Júnior et al., 1981; Bertolini and Lombardi Neto, 1994; Quevedo and Paganini, 2011).

In domestic sewage, phosphorus appears as organic compounds such as proteins and mineral compounds, mainly orthophosphates. This is because, in addition to its organic origin through defecation, phosphorus is also widely used as a raw material for many industrialized processes, which are consumed or used in the home by human beings, from pharmaceuticals to food and cleaning products. The concentration of phosphorus in domestic sewage is around 4 to $50 \mathrm{mg} \mathrm{L}-1$, related to a daily production of 1 to $3 \mathrm{~g}$ per person. In Brazil, the daily phosphorus contribution per capita in domestic sewage is considered in the range of 1.0 and 1.3g per person (Von Sperling et al., 2009; Randall et al., 2010; Jordão and Pessôa, 2011; Metcalf \& Eddy et al., 2014; Von Sperling, 2016).

In places where sodium tri-polyphosphate (STPP) powdered detergents are used for washing clothes, an average of $50 \%$ of the phosphorus present in sewage comes from this source (IJC, 1970; Litke, 1999; Glennie et al., 2002). In Brazil, as powdered detergents available in the market have a low concentration of phosphorus, the amount of the nutrient discharged into rivers from this source is small, about $0.17 \%$ of the total amount of phosphorus present in the wastewater. Considering this result and based on sample-collection campaigns carried out in different sewage treatment plants located in the State of São Paulo, Quevedo and Paganini (2016) calculated the current daily average phosphorus per capita contribution in sewage, in the range of $0.9 \mathrm{~g}$ per person.

From the 1960s onward, with the decline in water quality due to eutrophication, many countries started to discuss the sources of phosphorus. These discussions gave way to studies about the availability of phosphorus, biological productivity and fertilization.

Subsequently, the use of STPP in detergents was restricted, particularly in Europe and North America, as it was considered to be an important source of phosphorus in sanitary 
sewage. For example, countries such as Switzerland, Germany and Holland decided to ban the use of phosphorus in detergents; in the United States, 27 states prohibited its use. Phosphorus was substituted by raw materials, such as zeolites. Later, in the 1990s, these countries started to adopt criteria to remove phosphorus from sewage treatment systems by establishing priorities for directing investment (IJC, 1970; Schmidtke, 1980; EC, 1991; Litke, 1999; Mauch et al., 2000; Staffel-Schierhof, 2001; Glennie et al. 2002; Friedman, 2004; IJC, 2014).

Sewage treatment systems for disposing of phosphorus in the soil allow plants to absorb and use this nutrient in their metabolic processes. They are thus an important alternative for treatment and reuse, contributing to the reloading of aquifers. It is also a recycling method as phosphorus that is present in liquid mass and precipitated in sludge in conventional sewage and effluent treatment processes is normally sent for incineration or for end disposal in landfill sites, and therefore is irredeemably lost (Von Sperling et al., 2009).

In agriculture, measures to control the loss of phosphorus are also related to controlling eutrophication, with actions for monitoring and controlling the amount of fertilizers being implemented, as well as measures for optimizing the use and management of fertilizers according to different cultivations and types of soil, so as to improve the control of productive processes, making them more sustainable.

In the United States, for example, the Nonpoint Source Management Program, established in 1987, awarded a government subsidy for carrying out activities related to education, technical assistance, training and the transfer of technology to programs to control diffuse pollution in agricultural areas. Various states set limits on phosphorus concentration in soils for agricultural use, providing recommendations related to more appropriate management of water basins in order to prevent the loss of nutrients and other environmental consequences (Litke, 1999; Glennie et al. 2002).

In Brazil, the issue of the impact of human activities on the phosphorus cycle has been discussed in terms of controlling urban sources in relation to the presence of phosphates in water systems which receive effluents. There are also discussions about restricting the amount of phosphorus in powdered detergents for domestic laundry use. In this case, the matter is regulated by CONAMA Resolution $\mathrm{n}$. 359/2005, which established the gradual reduction of this element to a maximum of $10.99 \%$ in phosphate weight and $4.8 \%$ in phosphorus weight in its elemental form by the end of 36 months from the year 2008 (Conama, 2005). Regarding to the agricultural use of phosphorus, discussions in Brazil have just started and there is no specific legislation for regulation in this area or any directives for using phosphate fertilizers.

\subsection{Scarcity of phosphorus reserves}

Phosphorus reserves started to be exploited for commercial purposes in the mid-19th century, due to its use in fertilizers. From the beginning of the 20th Century, due to industrial and technological development, other phosphorus-based products started to be produced and the element became even more important economically, resulting in the intensification of its rate of exploitation.

The comparison between the amount of phosphorus put into the cycle, which is constantly increasing, and its rates of return allows us to see that a certain amount of this element may be irreversibly lost or available in the wrong place. This situation may have a very significant effect on the sustainability of the environment and quality of life, as it is an irreplaceable nutrient in all biological processes and a finite natural and non-renewable resource with no alternative sources.

Based on data about available reserves and according to existing current demands, Cordell et al. (2011) points to the probable occurrence of a peak in exploitation of phosphatic rock reserves in the world around 2030. After this time, due to the exponential growth in the world population projected for the next fifty years, it is estimated that the availability of reserves and 
the ability to exploit them will be gradually reduced, being impacted by an increase in the cost of operation, a reduction in quality and an rise in the degree of technical difficulty in order to access remaining reserves. Thus, at the current rate of exploitation and from expected population growth forecasts, we can estimate that known and exploitable phosphatic rock reserves will be extinct within a period of between 50 and 100 years.

Malavolta (2004), following Rieder (1986), makes a projection, in percentage terms, of the situation of the Brazilian and world phosphatic rock reserves in face of a rise in the demand for phosphate, and estimates that world reserves may last 70 years if there is a $6 \%$ increase in demand or 210 years if this rise in demand is $1 \%$. In the case of Brazilian reserves, under the same percentage growth conditions, the length of time reserves will last may be either 40 or 120 years. This may be observed in Figure 1.

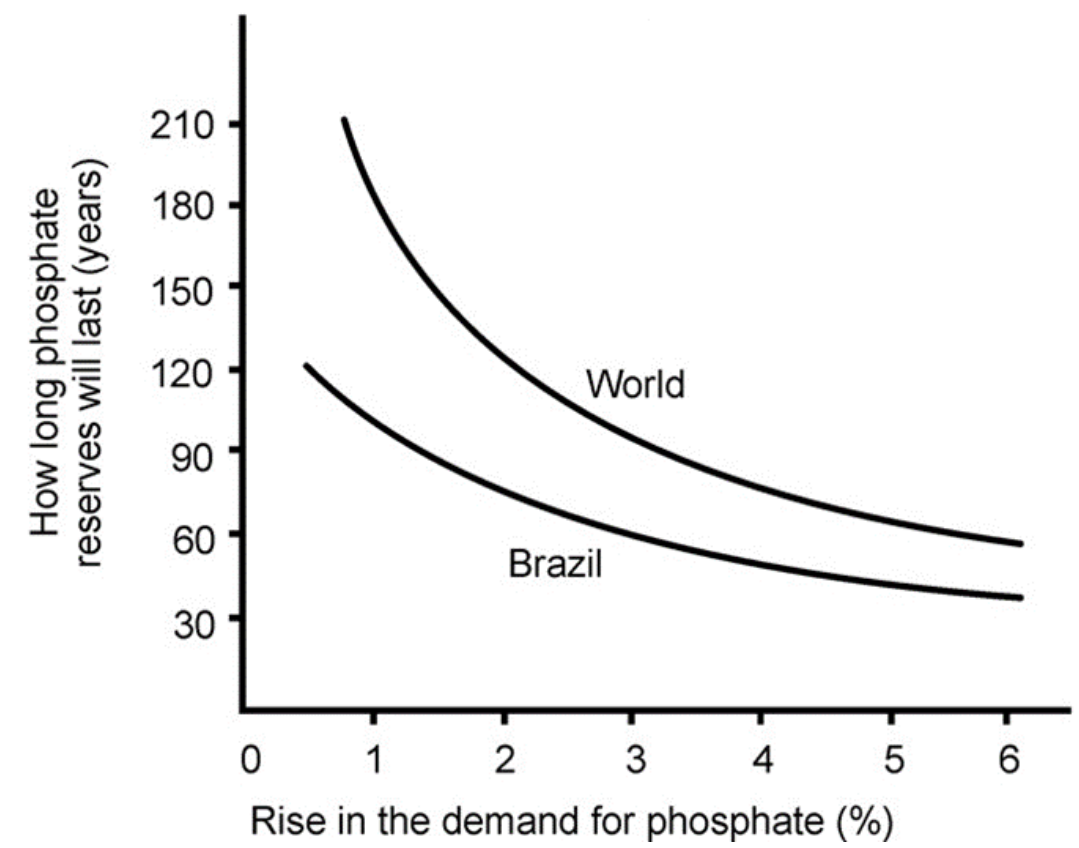

Figure 1. Estimates of how long phosphate reserves will last in Brazil and the World.

Source: Malavolta, 2004.

However, some recent studies have argued in favor of a possible change in the predicted velocity of depletion of phosphate reserves, due to the increasingly stringent discharge regulations and the development of new technologies to achieve new rock reserves. Several researchers also discuss the contribution of various P-recovery techniques from wastewater and food waste, as well the role of other works aiming at increasing efficiency in the use of phosphorus-based products and yield gains in crop and livestock systems. Because of this, the matter of the phosphate natural rock reserves has been under constant review (Edixhoven et al., 2014; Desmidt et al., 2015; Neset et al., 2016).

Within this context, there is growing concern regarding measures to recover phosphorus, so as to stimulate its recycling, in particular in areas used for agriculture production. Policymaking, which can assist with the cycling of phosphorus through the market by means of fertilization of agricultural areas, is very important for reducing undesired effects in the environment and for improving efficiency in the use of available natural resources.

\subsection{The importance of the management tools: cleaner production $(\mathrm{CP})$}

The expression 'Cleaner Production' was created in 1989 by the United Nations 
Environment Program (UNEP) and it is a continuous management strategy aimed at making the productive process more efficient and less aggressive to man and the environment, bringing together economic and market aspects in the search for solutions to preserve the environment (Giannetti et al., 2003; SEBRAE, 2009).

Based on the concepts of pollution prevention, the aim of Cleaner Production (CP) is to help preserve the sources of raw materials, contribute to the development of products that have lower environmental impact during their life-cycle, reduce the risk of using toxic materials and decrease the amounts of residues and emissions produced. By managing environmental aspects, which occur during the various stages of the industrial process, corrective technologies, the socalled 'end of pipe' technologies, are substituted with preventive actions.

When these preventive actions are implemented individually, they can enhance environmental sustainability through the interaction of processes and systems, always taking into account the ecological characteristics of each region and the physical, economic and social environment within which they are inserted. (Giannetti et al., 2003)

The introduction of CP tools can assist in the implementation of changes, which reduce the impact of human interference on the phosphorus cycle. These tools can stimulate improvements in productive processes, whether related to the extraction of the raw materials or to its employment in productive processes and the treatment of residues and effluents produced. They can also help industries to comply generally with the law and respect limits established by legislation in order to promote changes in behavior and attitude on the part of both producers and consumers. It is a strategy that integrates economic, institutional and social issues with the need to preserve the natural phosphorus cycle in order to ensure environmental sustainability in a continuous and permanent way.

In consideration of the evidence presented, it is important to emphasize certain actions related to phosphorus management (Lloyd, 2007; Neset et al., 2016):

- Develop technology in order to increase the percentage of raw material recovery during mining and processing activities so as to optimize phosphate reutilization in the production process;

- Regulate phosphorus in industrialized products or substitute it with alternative materials, for example in detergents, thus reducing the quantity of undesirable phosphorus from wastewater and decreasing the rate of source exploitation;

- Make legislation on agronomic and product efficiency compatible in order to make mineral phosphates fertilization, management and acidity correction more efficient;

- In the field of genetically modified plants, develop varieties and species which are more efficient in using phosphorus, thus optimizing the plant, soil and nutrient relationship;

- Control the concentrations of phosphorus in the diet of animals and encourage the recycling of residues generated;

- Develop studies and regulate practices related to the disposal of sewage effluent and sewage sludge in the soil in order to use them in the irrigation and fertilization of cultivated areas;

- Draft policies that promote the cycling of nutrients through the economy, and in particular the fertilization of agricultural areas, through the implementation of techniques for reusing agricultural, industrial and urban residues;

- Set up environmental education programs about the importance of preserving phosphorus sources so as to reduce the generation of residues and control the use of fertilizers and detergents.

As such, the sustainable management of phosphorus involves both preserving reserves and safeguarding water quality. Actions may be proposed with a view to substituting this raw 
material, reducing the rate of source exploitation and introducing improvements to the productive process. All of this would contribute to the rationalization of phosphorus and the reutilization and recycling of residues originating in industrial processes, as well as residues from agricultural and urban activities such as wastewater, sewage sludge, animal excrement, and residues from slaughter houses, and food and agricultural residues. Figure 2 shows a schematic summary of human impact on the phosphorus cycle and the CP tools.

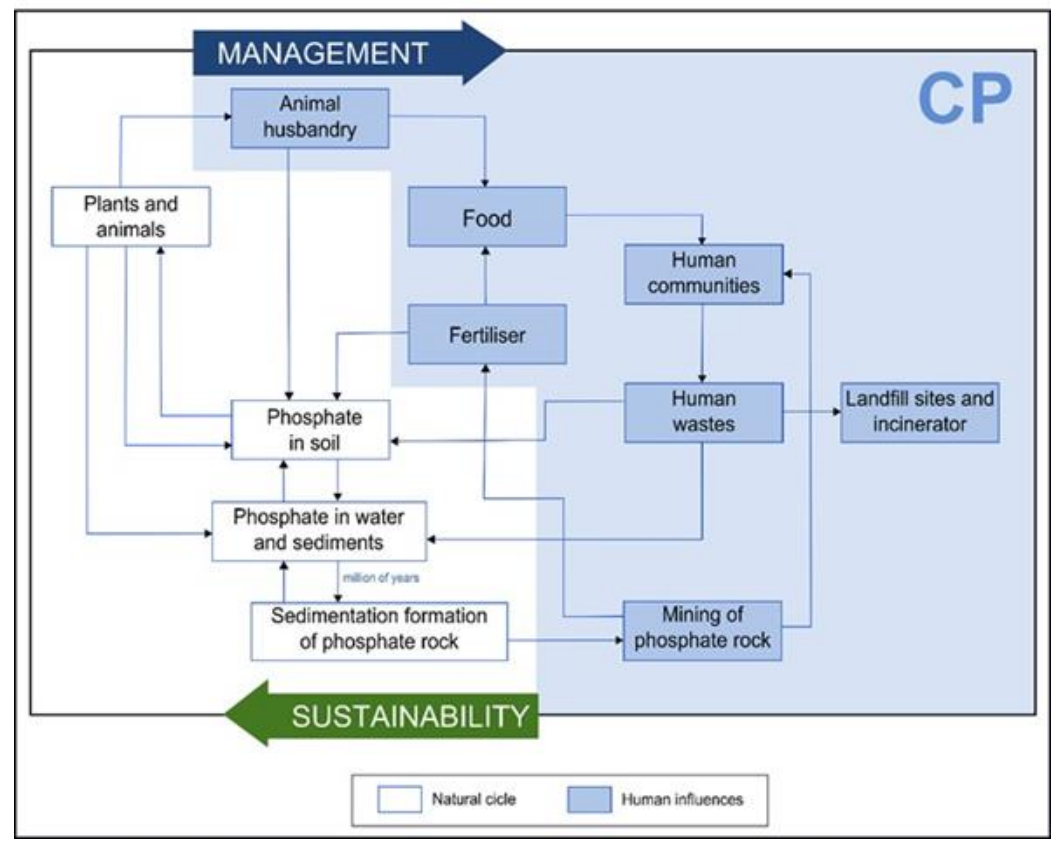

Figure 2. Phosphorus cycle, human impact and CP.

Source: Adapted from Lloyd (2007).

Alternatives for preventing pollution related to managing the use of phosphorus can assist in protecting the quality of water systems and reducing the costs of production. This is because investment in systems to treat effluents and money spent on dealing with residues can be optimized. For example, in a company which manufactures freezers, located in the state of Minnesota in the USA, the substitution of phosphorus for alternative materials during the washing and painting stages led to a $90 \%$ reduction in phosphorus emissions. This meant a $25 \%$ reduction in the overall amount of phosphorus present in sewage, with significant environmental, social and economic gains. This also resulted in being able to meet the emission restrictions established by the monitoring bodies and minimized the risks of receiving penalties (McComas and McKinley, 2008).

New technologies are also considered to be of fundamental importance for the sustainable use of phosphorus in industrial processes, as is the case, for example, in the process for recovering phosphorus from oyster shell residues by means of pyrolisis, and in the use of physicochemical or incineration processes for recovering phosphorus from sanitary sewage sludge, making it available for reuse (Jegatheesan et al., 2009; Mihelcic et al., 2011).

When preventive actions are implemented individually, they can enhance environmental sustainability through the interaction of processes and systems, always taking into account the ecological characteristics of each region and the physical, economic and social environment within which they exist. The Kalundborg Industrial Park in Denmark is an example of a complex that integrates a number of local small-, medium- and large-sized businesses, where the residues of one company are used as a source of energy by another company. This experience demonstrates that results benefit both businesses and the environment, pointing 
towards a significant reduction in energy consumption and carbon dioxide $\left(\mathrm{CO}_{2}\right)$ and sulphur $\left(\mathrm{SO}_{2}\right)$ emissions, a reduction in the volume of liquid effluents generated and an increase in the capacity for re-using traditional residues such as sulphur, ashes and iodine. A systemic vision of the environment and different units acting jointly in a particular region allow for the sustainable management of processes and residues, thus ensuring economic, social and environmental benefits (Ehrenfeld and Gertler, 1997; Giannetti et al., 2003).

An important way of reducing the impact of human activities on the phosphorus cycle and preventing the presence of undesirable quantities of this substance in the water system is through the control of the use of phosphorus-based industrialized products, such as detergents and fertilizers. It is therefore worth stressing certain measures that can assist in promoting changes in lifestyle and recycling techniques, as well as introducing better management practices in cultivated areas.

Studies carried out in Sydney, Australia by Tangsubkul et al. (2005) show that a combination of recycling sanitary sewage, composting sewage sludge and making changes in the urban population's consumer habits, such as the introduction of a vegetarian diet and the use of non-phosphorus detergents, is the most effective way of reducing the amounts of phosphorus released into the environment by urban effluents.

In Feixi, a region in Central China, Wu et al. (2012) observed that more than $90 \%$ of phosphorus losses were a result of agricultural activity. Fertilizers and mineral feed accounted for the main sources of these losses. In this case, it can be concluded that in agriculture, in addition to better management practices, there is a need for more effective legal mechanisms for controlling the use of fertilizers and encouraging the recycling of animal residues in cultivation.

Another measure adopted is the introduction of ecolabels for phosphate-free detergent. This is a type of "green seal". The aim of this labelling is to assist consumers in identifying products which cause less damage to the environment, in order to assist them in their consumer choices. As a result, manufacturers are encouraged to develop products and production processes which are more conducive to protecting the environment. These seals include the Nordic White Swan, used in Sweden, Finland, Denmark, Iceland and Norway, and the Ecolabel, used in European Union countries (Glennie et al., 2002).

Within this context, the introduction of $\mathrm{CP}$ as a management tool can assist in the implementation of changes which reduce the impact of human interference on the phosphorus cycle. These mechanisms can stimulate improvements in productive processes whether related to the extraction of the raw material or to its employment in productive processes and the treatment of residues and effluents produced. They can also help industries to comply generally with the law and respect limits established by legislation in order to promote changes in behavior and attitude on the part of both producers and consumers. It is a strategy that integrates economic, institutional and social issues with the need to preserve the natural phosphorus cycle.

\section{MATERIAL AND METHODS}

This is a documental research, which deals with the dynamics of phosphorus in the environment, the impact of human activities for the presence of this nutrient in the water and measures for management and control. We present actions adopted for managing the input of phosphorus in water resources by the sewage in urban areas, as well as the situation prevalent in Brazil; with this in mind, we discuss the importance of regulating the use of phosphate detergents and introducing concepts of CP.

In order to obtain a better overview of the subject, situating it within the Brazilian reality, we carried out a data evolution analysis relative to the urban population in the water basin of the Tietê River for the period covering 1986 to 2016. Data was compiled from information 
made available by the System of Data Analysis Foundation of São Paulo State - SEADE, through its Information System on São Paulo Municipalities - IMP. The Tietê was chosen due to factors that provide it with specific characteristics, such as diversity of use and river basin occupation, contrasts in water quality and the prevalence of regions of intense urbanization with a high population concentration (Quevedo and Paganini, 2011; Seade, 2016).

Subsequently, we calculated the potential load of phosphorus discharged into the Tietê water through the sewage originating in the basin in 1986 and 2000. For this, we assumed the data on phosphorus contribution per capita in sewage of $1.3 \mathrm{~g}_{\text {inhab.day }}{ }^{-1}$, according to the classical literature on the subject (Von Sperling et al., 2009; Metcalf \& Eddy et al., 2014).

The percentage of the loads of phosphorus in sewage due to using phosphate detergents was estimated considering the results obtained in current legislation and in studies recently developed about this issue. These data point to a phosphorus concentration in detergents less than $0.01 \%$ by weight and a daily average phosphorus per capita contribution in sewage of 0.9 g per person (Conama, 2005; Quevedo and Paganini, 2016). We thus assessed what percentage of the load can be now prevented by controlling this source.

The potential of recycling phosphorus from sewage effluent and sludge was also covered, on the basis of the literature about this theme, inspiring a discussion on the possibility of reusing residues in the agricultural activities.

\subsection{Area of study: Water basin of the Tietê River, State of São Paulo, Brazil}

The Tietê River is $1,136 \mathrm{~km}$ in length and it crosses the State of São Paulo from east to west. The total area of its water basin is $71,381 \mathrm{~km}^{2}$ and it is the largest river basin in the State in territorial terms, equivalent to $28.7 \%$ of the total area of the state. It encompasses 233 municipalities, including important metropolitan areas and other regions of high demographic concentration such as the Metropolitan Region of the City of São Paulo and the Metropolitan Region of Campinas.

According to Brazilian law No. 9.034/94, which established the Water Resources State Plan, the Tietê basin is divided into six Water Resource Management Units (UGRHIs) as follows: Alto Tietê, Piracicaba/Capivari/Jundiaí, Tietê/Sorocaba, Tietê/Jacaré, Tietê/Batalha and Baixo Tietê. Figure 3 shows the distribution of the UGRHIs which make up the River Tietê basin.

In relation to its demography, SEADE shows that the urban population of the Tietê River basin went from 18.3 to 29.2 million inhabitants between 1986 and 2016. This means an increase of almost 11 million people in 20 years. About 6.6 million of this rise is found in the Alto Tietê UGRHI, 2.2 million in the Piracicaba/Capivari/Jundiaí UGRHI and 966,000 in the Tietê/Sorocaba UGRHI with expansion of $49 \%$, 99\% and $105 \%$ respectively (Quevedo and Paganini, 2011; Seade, 2016).

The rate of sewage collection in the basin is $94.5 \%$ and the rate of treatment of collected sewage is $76 \%$. In this way, the rate of sewage collection and treatment in the basin is $71.8 \%$. The largest part of existing systems are the so-called secondary level, aimed at removing biodegradable organic matter and solids in suspension. The sludge generated in existing treatment stations is mainly taken to landfill sites (Cetesb, 2016).

For agricultural areas, in São Paulo State there are more than 20 million hectares occupied by agricultural activities, totalling 324,602 Agricultural and Animal Farming Production Units (UPAs). Of these, almost 7 million hectares are used for growing non-perennial crops, such as sugarcane and sorghum. Over 52\% make use of fertilization with mineral phosphates (CATI, 2008). 


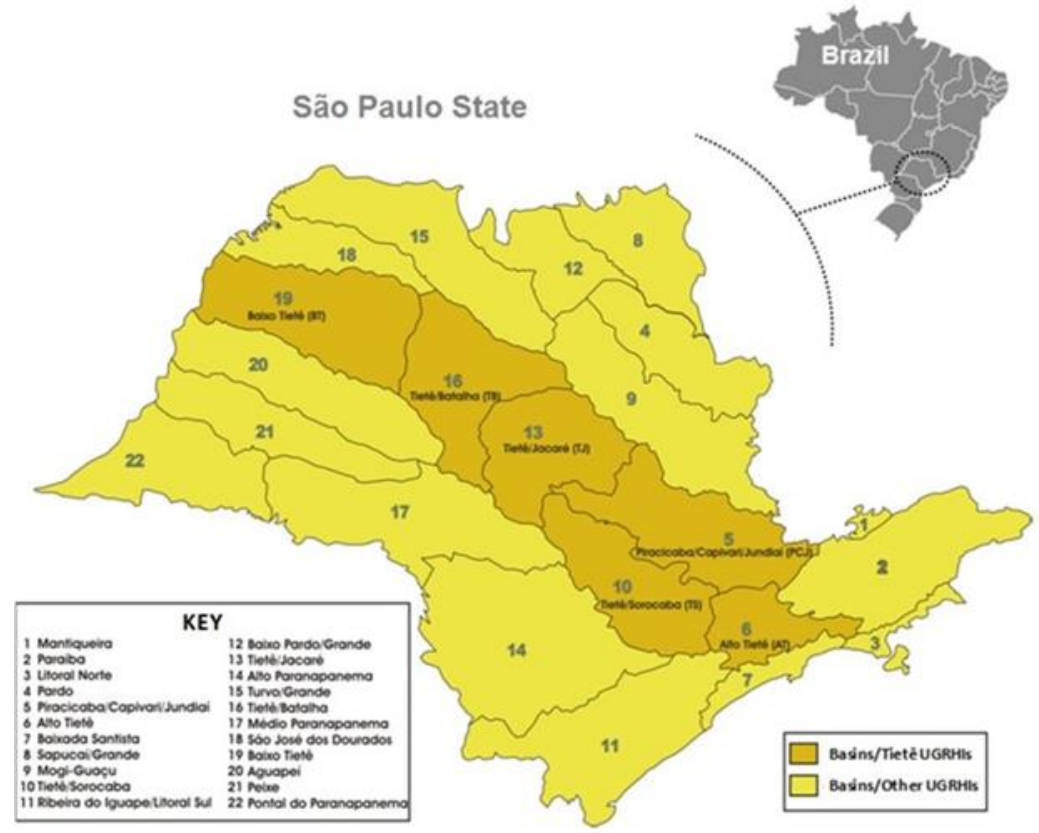

Figure 3. Location of UGRHIs belonging to the Tietê River basin.

\section{RESULTS AND DISCUSSION}

Analyzing urban population data regarding the period evaluated and the phosphorus contribution per capita in sewage, it can be observed that the potential phosphorus load discharged into sewage originating in the basin was almost $24 \mathrm{t} \mathrm{day}^{-1}$ in 1986, which was equivalent to $8,756 \mathrm{t}^{\text {year }}{ }^{-1}$. Over $74 \%$ of this total, that is, around $18 \mathrm{t}$ per day $^{-1}$ or 6,444 t year $^{-1}$, was coming from the Alto Tietê UGRHI, which includes the metropolitan region of the City of São Paulo.

In the year of 2000, the load of phosphorus coming from sewage originating in the basin rose to almost $32 \mathrm{t} \mathrm{day}^{-1}$ or 11,448 $\mathrm{t}_{\text {year }}{ }^{-1}$. This amount is related to the population growth in the basin during the period, increasing from almost 18 million to more than 24 million, comparing the years 1986 and 2000. Already in 2016, the quantity of phosphorus discharged in the waters of the Tietê was calculated in the range of $26 \mathrm{t} \mathrm{day}^{-1}$ or $9,593 \mathrm{t}^{\mathrm{year}}{ }^{-1}$, because of its replacement in powdered detergents. This represents a reduction of about $11.7 \mathrm{t} \mathrm{day}^{-1}$. This figure is based on the population growth and the values for phosphorus used in detergents formulas, as observed in studies recently developed about this issue that show the Brazilian products have less than $0.01 \%$ of phosphorus in the formula.

Table 1 shows the urban population in the Tietê basin in the years of 1986, 2000 and 2016, according to different UGRHIs, based on demographic data. It also gives the estimated loads of phosphorus into the water, according the potential contribution of the wastewater and because of the introduction of detergents with low phosphate content in the Brazilian market.

Besides the potential reduction in the emissions of phosphorus into water because of phosphorus replacement in detergents, the scenario of sewage treatment in the basin can affect the amount of phosphorus discharged into the Tietê river. It must be mentioned that the rate of sewage collection and treatment in the basin is around $71.8 \%$ and the largest part of existing sewage treatment plants are not designed for phosphorus removal. So it can be inferred that there is a large quantity of phosphorus discharged into Tietê waters from this source, contributing to eutrophication. 
Table 1. Urban population and the potential load of phosphorus in the Tietê River basin - Years 1986, 2000 and 2016.

\begin{tabular}{|c|c|c|c|c|c|c|c|}
\hline \multirow[t]{2}{*}{ UGRHI/Basin } & \multicolumn{3}{|c|}{$\begin{array}{l}\text { Urban Population - Year } \\
\text { (n. inhab) }\end{array}$} & \multicolumn{3}{|c|}{$\begin{array}{c}\text { Phosphorus Load in } \\
\text { Sewage - Potential } \\
\text { Contribution - Year } \\
\text { (t day) }\end{array}$} & \multirow[t]{2}{*}{$\begin{array}{l}\text { Phosphorus } \\
\text { Load in } \\
\text { Sewage - } \\
\text { Potential } \\
\text { Reduction } \\
\text { (t day) }\end{array}$} \\
\hline & 1986 & 2000 & 2016 & $1986^{1}$ & $2000^{1}$ & $2016^{2}$ & \\
\hline Alto Tietê & $13,580,958$ & $16,982,976$ & $20,197,071$ & 17.66 & 22.08 & 18.18 & 8.08 \\
\hline Piracic/Capiv/Jund & $2,269,934$ & $3,520,593$ & $4,527,102$ & 2.95 & 4.58 & 4.07 & 1.81 \\
\hline Tietê/Sorocaba & 918,381 & $1,444,508$ & $1,884,566$ & 1.19 & 1.88 & 1.70 & 0.75 \\
\hline Tietê/Jacaré & 875,863 & $1,251,107$ & $1,498,510$ & 1.14 & 1.63 & 1.35 & 0.60 \\
\hline Tietê/Batalha & 263,633 & 377,734 & 449,611 & 0.34 & 0.49 & 0.40 & 0.18 \\
\hline Baixo Tietê & 439,758 & 549,383 & 645,174 & 0.57 & 0.71 & 0.58 & 0.26 \\
\hline Tietê River Basin & $18,348,527$ & $24,126,301$ & $29,202,035$ & 23.85 & 31.36 & 26.28 & 11.68 \\
\hline
\end{tabular}

1- Per capita contribution of phosphorus assumed as $1.3 \mathrm{~g}$ inhab.day ${ }^{-1}$.

2- Per capita contribution of phosphorus calculated at $0.9 \mathrm{~g}_{\text {inhab.day }}{ }^{-1}$.

The introduction of $\mathrm{CP}$ concepts in sewage treatment plants could contribute towards using a finite natural resource with greater effectiveness by introducing concepts of residue recycling and recovery. This could strengthen the results reached by the replacement of phosphorus in the powder detergents, thus contributing towards improving the quality of water resources.

Alternatives that could contribute towards increasing phosphorus rates of return to its natural cycle should be taken into account. One such initiative for example includes the systems of effluent and sewage disposal in the soil. In this case, potential sources of pollution from the liquid phase of the domestic sewage, as organic matter and nutrients, could be transformed into sources of productivity and sustainability.

The agricultural reuse of domestic sewage is a widespread practice in many countries, such as China, Israel, Mexico and Germany, among others. In Brazil, there is a number of studies focused on this type of initiative under the Program of Research on Basic Sanitation (PROSAB), but the practice is not being applied uniformly throughout the country. Many environmental benefits have been related to the agricultural reuse of sewage, such as the reduction of effluent discharges to sensitive water bodies, the preservation of groundwater resources, the recycling and recovery of nutrients and organic matter, and the restoration of soil conditions. Some economic advantages are also reported (Piveli et al, 2009). However, some specific care has to be taken in order to prevent the accumulation of pollutants in soil and groundwater, and to reduce risks to public health.

Another initiative that considers CP concepts in this area is the recycling of sewage sludge, which is the solid phase of a sewage treatment process. There are several studies worldwide to investigate the possible recovery of phosphorus and other nutrients from this source. The main beneficial uses of sludge and biosolids include agricultural production, rehabilitation of degraded areas, energy generation and recovery, landscaping and forest-area management. It is also possible to recycle phosphorus in sludge by adding magnesium and adjusting the $\mathrm{pH}$, for instance, through crystallization of mono amino phosphate $\left(\mathrm{MgNH}_{4} \mathrm{PO}_{4}\right)$, called struvite. Such a process may provide commercial advantages once the struvite can be used as raw material for the fertilizer industry (Metcalf \& Eddy et al., 2014).

It is important to mention that the amount and composition of the sludge are quite variable according to the sewage characteristics and the treatment plant design. Other factors that can 
influence the sludge characteristics are the technologies adopted for digestion, dewatering and drying. For biological sewage treatment systems of the activated sludge process, for instance, one of the main sewage treatment systems used in Brazil, the amount of dewareted sludge usually produced ranges from 35 to $90 \mathrm{~L}$ inhab.year ${ }^{-1}$. On the other hand, for the physicalchemical treatment process, the amount of sludge can be 7 times higher (Von Sperling, 2016). The typical content of phosphorus in the sludge of biological sewage treatment systems by the activated sludge process is usually in the range of $2.5 \% \mathrm{P}$ (Van Haandel et al., 2009).

On this basis, as an illustration, in a scenario of adoption of biological sewage treatment by the activated sludge process for the sewage generated in the urban areas of the Tietê river basin, for instance, the amounts of sewage sludge generated that could have beneficial uses can be calculated in the range of 3,080 to 7,921 t day ${ }^{-1}$. Of this amount, around 77 to $198 \mathrm{t} \mathrm{day}^{-1}$ of phosphorus could potentially be recovered. This inference is for explanatory purposes only and does not consider other technical or environmental criteria that could affect the treatment process or the sludge production. However, it shows the amount of phosphorus in biosolids that could potentially be recycled in agricultural areas, reducing the amount of sludge sent to landfill sites, increasing phosphorus recovery rates, and contributing to a reduction in the consume of chemical fertilizers. Table 2 shows this calculation.

Table 2. Estimated amounts of sewage sludge and phosphorus that could potentially be recycled in the Tietê River basin - Year 2016.

\begin{tabular}{lccc}
\hline UGRHI/Basin & $\begin{array}{c}\text { Urban Population } \\
\text { (n. inhab) }\end{array}$ & $\begin{array}{c}\text { Sewage Sludge } \\
\text { (t day) }\end{array}$ & $\begin{array}{c}\text { Phosphorus in Sewage Sludge }^{2} \\
\text { (t day) }\end{array}$ \\
\hline Alto Tietê & $20,197,071$ & $2,130-5,478$ & $53-137$ \\
Piracic/Capiv/Jund & $4,527,102$ & $478-1,228$ & $12-31$ \\
Tietê/Sorocaba & $1,884,566$ & $199-511$ & $5-13$ \\
Tietê/Jacaré & $1,498,510$ & $158-406$ & $4-10$ \\
Tietê/Batalha & 449,611 & $47-122$ & $1-3$ \\
Baixo Tietê & 645,174 & $68-175$ & $2-4$ \\
\hline Tietê River Basin & $\mathbf{2 9 , 2 0 2 , 0 3 5}$ & $\mathbf{3 , 0 8 0 - 7 , 9 2 1}$ & $\mathbf{7 7 - 1 9 8}$ \\
\hline
\end{tabular}

1- Per capita generation of sewage sludge is considered in the range of 35 to $90 \mathrm{~L}_{\text {inhab.year }}{ }^{-1}$.

2 - Typical content of phosphorus in the sludge of sewage treatment by activated sludge process as $2.5 \% \mathrm{P}$.

Urban and Isaac (2016) calculated the feasibility of sewage sludge application in the Piracicaba, Capivari and Judiaí (PCJ) UGRHI, which belong to the Tietê River basin. They considered the areas occupied by different crops and classified those areas based on the less risks for this operation in face of environmental conditions as topography, existence of aquifers, presence of watercourses, texture and other characteristics of soil and extension of conservation areas. They designed the so-called "aptitude maps" for accepting sewage sludge. The study shows that 1.7 million hectares occupied by sugarcane crops and reforestation in the PCJ region is able to receive sewage sludge in an estimated amount of 2.6 million $t$ year ${ }^{-1}$ or $547 \mathrm{t} \mathrm{day}^{-1}$. Comparing this information to the data showed in Table 2, it can be inferred that there is a great potential for re-using and recycling phosphorus in the Tietê basin.

In Brazil, the discussions related to the beneficial use of biosolids and nutrient recovery have just begun and there are no specific directives for using phosphate fertilizers. In addition, current Brazilian legislation has strict standards for the use of sewage sludge. This is because the practice requires special precautions regarding the control of pathogens, metals, organic compounds and other pollutants whose human and environmental interactions are still under investigation (Piveli at al., 2009; Metcalf \& Eddy at al., 2014; Urban and Isaac, 2016; Von Sperling, 2016). Nevertheless, from the perspective of pollution control and prevention, and in face of the CP concepts, the agricultural use of biosolids cannot be considered as a remote 
alternative for final disposal of sewage sludge. In this regard, the potential of recycling and recovery phosphorus from the liquid phase of the sewage treatment process must not be forgotten either.

Alongside the sewage issue, it should be noted that concerning the management of phosphorus in water, other actions of a preventative nature are also of fundamental importance. This includes the regulation of the composition and the use of products containing phosphorus in their formulae, such as fertilizers and animal-based food, in line with what was done for the detergents. The introduction of alternative raw materials and the development of technologies with a view to using domestic, industrial and agricultural residues with phosphorus content must also be mentioned.

Another important point is public involvement and awareness. Measures geared towards promoting changes in behavior and attitude related to the use of phosphorus on the part of producers, consumers and the population in general can make $\mathrm{CP}$ concepts more feasible. This is because they aim to teach people about the impact of the presence of phosphorus in water, the effects of its scarcity and the importance of adopting measures to control and restrict its use. Hence, "green seal" initiatives for detergents with no phosphorus, for instance, which have already been widely adopted in many countries, are of great significance.

\section{CONCLUSIONS}

The management and control of the sources of phosphorus is considered to be of great importance in order to improve the quality of the water systems. Measures geared towards promoting changes in behavior and attitude related to the use of phosphorus on the part of producers, consumers and the population in general may contribute to teach people about the impact of the presence of phosphorus in water, the effects of its scarcity and the importance in adopting measures to control and restrict its use. In the case of the Tietê River basin, there could be a reduction of approximately $11.7 \mathrm{t} \mathrm{day}^{-1}$ of phosphorus because of its replacement in powdered detergents formulae by other raw materials.

In addition, wastewater can potentially be an important material for the reuse and recycling of phosphorus, through the interaction of urban and agricultural systems, taking into account the ecological, physical and economic characteristics of each region. For that, it is necessary to develop knowledge related to the disposal of sanitary sewage and sewage sludge, with the goal of ensuring safety and environmental protection.

In order to advance more sustainable means of production and consumption, management tools such as the CP concepts may be considered an important skill. They can stimulate producers in complying with environmental legislation and assist in the planning of public policies promoting the sustainability of the environment. They are both a management strategy and a tool for preventing pollution. They can align economic and technological objectives with the necessity of conserving the environment and the promoting public health in an integrated way.

\section{ACKNOWLEDGMENTS}

This study was developed at University of Sao Paulo (USP).

\section{REFERENCES}

BELLINAZZI JÚNIOR, R.; BERTOLINI, D.; LOMBARDI NETO, F. Occurrence of erosion in São Paulo State. In: SYMPOSIUM ON EROSION CONTROL, 2., 1981, São Paulo. Anais... São Paulo: ABGE, 1981, p.117-137. 
BERTOLINI, D.; LOMBARDI NETO, F. Technical basis of the watersheds state program. In: Technical guide of soil and water management and conservation. Campinas: CATI, 1994. p. 1-15.

BRAILE, P. M.; CAVALCANTI, J. E. W. A. Wastewater treatment manual. São Paulo: CETESB, 1993.

CHAVE, P. A. Legal and regulatory instruments. In: HELMER, R.; HESPANHOL, I. (Eds.). Water pollution control: a guide to the use of water quality management principles. London: WHO/UNEP, 1997.

CORDELL, D.; ROSEMARIN, A.; SCHRÖDER, J. J.; SMIT, A. L. Towards global phosphorus security: a systems framework of phosphorus recovery and reuse options. $\begin{array}{lllllll}\text { Chemosphere, } & \text { v. } & 84, & \text { n. } & 6, & \text { p. } & 747-758,\end{array}$ http://dx.doi.org/10.1016/j.chemosphere.2011.02.032

DESMIDT, E.; GHYSELBRECHT, K.; ZHANG, Y.; PINOY, L.; BRUGGEN, B. V.; VERSTRAETE, W. et al. Global phosphorus scarcity and full-scale P-recovery techniques: a review. Critical Reviews in Environmental Science and Technology, v. 45, n. 4, 2015. http://dx.doi.org/10.1080/10643389.2013.866531

ENVIRONMENTAL SANITATION TECHNOLOGY COMPANY - CETESB. Report on the quality of inland water. São Paulo: CETESB, 2016.

EUROPEAN COMMISSION - EC. Council Directive no 271, of 21 May 1991. Concerning urban wastewater treatment. Brussels, 1991.

EDIXHOVEN, J. D.; GUPTA, J.; SAVENIJE, H. H. G. Recent revisions of phosphate rock reserves and resources: a critique. Earth System Dynamics, n. 5, p. 491-507, 2014. http://dx.doi.org/10.5194/esd-5-491-2014

EHRENFELD, J.; GERTLER, N. Industrial ecology in practice: the evolution of interdependence at Kalundborg. Journal of Industrial Ecology, v. 1, n. 1, p. 67-79, 1997. http://dx.doi.org/10.1162/jiec.1997.1.1.67

FOUNDATION STATE SYSTEM OF DATA ANALYSIS - SEADE. Information System on São Paulo Municipalities (IMP). São Paulo, 2016.

FRIEDMAN, M. Detergents and the environment: historical review. In: ZOLLER, U. (Ed.). Handbook of detergents - part B: environmental impact. New York: Marcel Dekker, 2004. p. 11-34.

GIANNETTI, B. F.; ALMEIDA, C. M. V. B.; BONILLA, S. H. Implementação de ecotecnologias rumo à ecologia industrial. RAE Eletrônica, v. 2, n. 1, p. 1-19, 2003. http://dx.doi.org/10.1590/S1676-56482003000100011

GLENNIE, E. B.; LITTLEJOHN, C.; GENDEBIEN, A.; HAYES, A.; PALFREY, R.; SIVIL, D. et al. Phosphates and alternative detergent builders: final report. Wiltshire: EU Environment Directorate, 2002.

INTEGRAL TECHNICAL ASSISTANCE COORDINATION - CATI. Agricultural producer units of the São Paulo state census. São Paulo: SAA/CATI/IEA, 2008.

INTERNATIONAL JOINT COMMISSION - IJC. Pollution of Lake Erie, lake Ontario and the international section of St. Lawrence River. International Lake Erie Water Pollution Board and the International Lake Ontario - St Lawrence River Water Pollution Board. Ontario, 1970. Vol. 3. p. 329. 
INTERNATIONAL JOINT COMMISSION - IJC. A balanced diet for Lake Erie: reducing phosphorus loadings and harmful algal blooms. Report of the Lake Erie Ecosystem Priority. Washington, 2014. 95 p.

JEGATHEESAN, V.; LIOW, J. L.; SHU, L.; KIM, S. H.; VISVANATHAN, C. The need for global coordination in sustainable development. Journal of Cleaner Production, v. 17, n. 7, p. 637-643, 2009. http://dx.doi.org/10.1016/j.jclepro.2008.11.016

JORDÃO, E. P.; PESSÔA, C. A. Wastewater treatment. $6^{\text {th }}$ ed. Rio de Janeiro: ABES, 2011.

LITKE, D. W. Review of phosphorus control measures in the United States and their effects on water quality. Colorado: USGS, 1999.

LLOYD, J. The nutrient cycle: closing the loop. United Kingdom: Green Alliance, 2007.

MALAVOLTA, E. Phosphorus in the plant and interactions with other elements. In: YAMADA, T.; ABDALLA, S. R. S. (Eds.). Phosphorus in Brazilian agriculture. Piracicaba: Potafos, 2004. p. 13-33.

MAUCH, C.; REYNARD, E.; THORENS, A. Historical profile of water regime in Switzerland (1870 - 2000). Working Paper. Geneve: IDHEAP, 2000.

METCALF \& EDDY; TCHOBANOGLOUS, G.; STENSEL, H. D.; TSUCHIHASHI, R.; BURTON, F. L. Wastewater engineering: treatment and resource recovery. New York: McGraw-Hill, 2014.

McCOMAS, C.; McKINLEY, D. Reduction of phosphorus and other pollutants from industrial dischargers using pollution prevention. Journal of Cleaner Production, v. 16, n. 6, p. 727-733, 2008. http://dx.doi.org/10.1016/j.jclepro.2007.02.023

MIHELCIC, J. R.; FRY, L. M.; SHAW, R. Global potential of phosphorus recovery from urine and feces. Chemosphere, v. 84, n. 6, p. 1879-1298, 2011. http://dx.doi.org/10.1016/j.chemosphere.2011.02.046

NATIONAL COUNCIL OF ENVIRONMENT - CONAMA. Resolução no 359 de 29 de abril de 2005. Dispõe sobre a regulamentação do teor de fósforo em detergentes em pó para uso em todo o território nacional e dá outras providências. Diário Oficial [da] União, Brasília, n. 83, p. 63, 03 maio 2005, Seção 01.

NESET, T. S.; CORDELL, D.; MOHR, S.; VANRIPER, F.; WHITE, S. Visualizing alternative phosphorus scenarios for future food security. Frontiers in Nutrition, v. 47, n. 3, 2016. http://dx.doi.org/10.3389/fnut.2016.00047

PIVELI, R. P.; CORAUCCI FILHO, B.; MONTES, C. R.; NASCIMENTO, C. W. A.; MOTA, S.; MARQUES JÚNIOR, J. et al. Agricultural use of sewage effluents: inputs of water and nutrients. In: MOTA, F. S.; VON SPERLING, M. (Coords.). Sewage nutrients: use and removal. Rio de Janeiro: ABES, 2009. p. 52-118.

QUEVEDO, C. M. G.; PAGANINI, W. S. Impacts of activities on the phosphorus dynamics in the environment and their reflections on public health. Ciência \& Saúde Coletiva, v. 16, n. 8, p. 3529-3539, 2011. http://dx.doi.org/10.1590/S1413-81232011000900021

QUEVEDO, C. M. G.; PAGANINI, W. S. Detergents as a source of phosphorus in sewage: the current situation in Brazil. Water, Air \& Soil Poll, v. 227, n. 14, 2016. http://dx.doi.org/10.1007/s11270-015-2700-3. 
RANDALL, C.; BARNARD, J.; STENSEL, H. D.; DUFRESNE, L. Nutrient control design manual. Cincinnati: USEPA, 2010. (Task Order, 68)

RIEDER, J. H. Destinação racional dos jazimentos fosfáticos nacionais. In: ENCONTRO NACIONAL DE ROCHAS FOSFATADAS, 3., 1986, Brasília. Anais... Brasília: IBRAFOS, 1986. p. 139-170.

SERVIÇO BRASILEIRO DE APOIO ÀS MICRO E PEQUENAS EMPRESAS - SEBRAE. Support Service for Small and Micro Businesses in the State of São Paulo. São Paulo, 2009.

SHARPLEY, A. N.; DANIEL, T.; SIMS, T.; LEMUNYON, J.; STEVENS, R.; PARRY, R. Agricultural phosphorus and eutrophication. Washington: USDA-ARS, 2003.

SCHMIDTKE, N. W. Nutrient removal technology: the Canadian connection. In: USEPA. Control of nutrients in municipal wastewater effluents. Volume I: Phosphorus. California, 1980, p. 1-37.

STAFFEL-SCHIERHOFF, U. Pollutant: group oriented action concepts illustrated by the example of nutrient reduction. In: RUDOLPH, K. (Ed.). The German Water Sector: Policies and Experiences. Bonn: Federal Ministry for the Environment, Nature Conservation and Nuclear Safety; Berlin: Federal Environmental Agency, 2001.

TANGSUBKUL, N.; MOORE, S.; WAITE, T. D. Incorporating phosphorus management considerations into wastewater management practice. Environmental Science \& Policy, v. 8, n. 1, p. 1-15, 2005. http://dx.doi.org/10.1016/j.envsci.2004.08.009

URBAN, R. C.; ISAAC, R. L. Land feasibility map for sewage sludge application: watershed of the Piracicaba, Capivari and Jundiaí Rivers - Brazil. Revista Ambiente \& Água, v. 11, n. 1, 2016. http://dx.doi.org/10.4136/1980-993X

VAN HAANDEL, A. C.; GIRARD, L.; MENDONÇA, N.; TEIXEIRA, M.; VON SPERLING, M. Biological phosphorus removal in activated sludge system: mechanisms and configurations. In: MOTA, F. S.; VON SPERLING, M. (Coords.). Sewage nutrients: use and removal. Rio de Janeiro: ABES, 2009. p. 227-261.

VOLLENWEIDER, R. A. Scientific fundamentals of the eutrophication of lakes and flowing waters, with particular reference to nitrogen and phosphorus factors in eutrophication. Tech. Report. DAS/CSI6827. Paris: OECD, 1968.

VON SPERLING, M.; ANDRADE NETO, C. O.; VOLSCHAN JÚNIOR, I.; FLORÊNCIO, L. Impact of sewage nutrients input in water bodies. In: MOTA, F. S.; VON SPERLING, M. (Coords.). Sewage nutrients: use and removal. Rio de Janeiro: ABES, 2009. p. 2651.

VON SPERLING, M. Urban wastewater treatment in Brazil. Washington: Inter-American Development Bank, 2016. (Technical Note $\mathrm{n}^{\circ}$ IDB-TN-970).

WU, H.; YUAN, Z.; ZHANG, L.; BI, J. Eutrophication mitigation strategies: perspectives from the quantification of phosphorus flows in socioeconomic system of Feixi, Central China. Journal of Cleaner Production, v. 23, n. 1, p. 122-137, 2012. http://dx.doi.org/10.1016/j.jclepro.2011.10.019 